\title{
ИССЛЕДОВАНИЕ ИЗМЕНЕНИЙ НОРМАТИВНО-ПРАВОВОЙ БАЗЫ В СФЕРЕ ЗЕМЛЕУСТРОЙСТВА
}

\section{Наталья Олеговна Митрофанова}

Сибирский государственный университет геосистем и технологий, 630108, Россия, г. Новосибирск, ул. Плахотного, 10, кандидат технических наук, доцент кафедры кадастра и территориального планирования, тел. (383)344-31-73, e-mail: kadastr-204@yandex.ru

\section{Надежда Ивановна Добротворская}

Сибирский государственный университет геосистем и технологий, 630108, Россия, г. Новосибирск, ул. Плахотного, 10, доктор сельскохозяйственных наук, профессор, профессор кафедры кадастра и территориального планирования, тел. (383)344-31-73, e-mail:kadastr-204@yandex. ru

\section{Владимир Игоревич Норкин}

Сибирский государственный университет геосистем и технологий, 630108, Россия, г. Новосибирск, ул. Плахотного, 10, соискатель, тел. (913)703-86-86, e-mail: norkin@innsk.org

\section{Ангелина Сергеевна Свирина}

Сибирский государственный университет геосистем и технологий, 630108, Россия, г. Новосибирск, ул. Плахотного, 10, обучающийся, тел. (383)344-31-73, e-mail: svirina1998@mail.ru

В статье рассмотрены современные проблемы, связанные с использованием земельных ресурсов в России, в частности, современное состояние сфере землеустройства. Основная проблема заключается в снижении роли землеустройства как научного и производственного явления, что приводит к принятию необъективных решений по планировке территории, использования земельных ресурсов и в целом к снижению эффективности управления земельно-имущественным фондом страны.

Цель исследования заключается в рассмотрении изменений в законодательстве, регулирующем землеустройство. В результате исследования проведена оценка эффективности современных землеустроительных мероприятий, а также сравнение содержания двух федеральных законов. Сделаны выводы о положительных изменениях законодательства в сфере землеустройства.

Ключевые слова: рациональное использование земель, охрана земель, землеустройство, схема землеустройства, почвенные обследования, внутрихозяйственное землеустройство, земли сельскохозяйственного назначения

\section{RESEARCH OF CHANGES IN THE REGULATORY AND LEGAL FRAMEWORK IN THE SPHERE OF LAND MANAGEMENT}

\section{Natalia O. Mitrofanova}

Siberian State University of Geosystems and Technologies, 10, Plakhotnogo St., Novosibirsk, 630108, Russia, Ph. D., Assoc. Prof., Department of Cadastre and Territorial Planning, phone: (923)137-18-88, e-mail: kadastr-204@yandex.ru

\section{Nadezhda I. Dobrotvorskaya}

Siberian State University of Geosystems and Technologies, 10, Plakhotnogo St., Novosibirsk, 630108, Russia, D. Sc., Assoc, Prof., Department of Cadastre and Territorial planning, phone: (383)344-31-73, e-mail: kadastr-204@yandex.ru

\section{Vladimir I. Norkin}


Siberian State University of Geosystems and Technologies, 10, Plakhotnogo St., Novosibirsk, 630108, Russia, Ph. D. Student, phone: (913)703-86-86, e-mail: norkin@innsk.org

\section{Angelina S. Svirina}

Siberian State University of Geosystems and Technologies, 10, Plakhotnogo St., Novosibirsk, 630108, Russia, Student, phone: (383)344-31-73, e-mail: svirina1998@mail.ru

The article deals with modern problems associated with the use of land resources in Russia, in particular, the current state of the field of land management. The main problem is to reduce the role of land management as a scientific and industrial phenomenon, which leads to the adoption of biased decisions on the planning of the territory, the use of land resources and, in general, to a decrease in the efficiency of management of the land and property fund of the country.

The purpose of the study is to consider changes in the legislation governing land management. As a result of the study, an assessment of the effectiveness of modern land management measures, as well as a comparison of the content of two federal laws, was carried out. Conclusions are drawn about positive changes in legislation in the field of land management.

Keywords: land management, land protection, land management, land management scheme, soil surveys, land management, agricultural land

В системе управления земельными ресурсами любой страны планирование использования земель и их охраны является, важнейшей функцией, определяющей перспективы рационального землепользования. Оно служит средством реализации земельной политики государств, а также увязки национальных, региональных и местных интересов при организации рационального использования земель и их охраны, учёта законных интересов граждан и всего общества, при обеспечении гарантий каждого гражданина на свободное владение, пользование и распределение земельными участками [1-8].

На территории России важнейшую роль в управлении земельными ресурсами играет землеустройство.

Под землеустройством в соответствии с действующим законодательством понимают мероприятия, направленные на организацию рационального использования земель, а также описание местоположения границ объектов землеустройства.

Экологическая эффективность землеустройства проявляется через влияние землеустроительных мероприятий на вид использования земли и находящуюся вокруг окружающую среду. К землеустроительным мероприятиям относят восстановление и консервацию земель, рекультивацию нарушенных земель, защиту земель от эрозии, подтопления, селей, иссушения, заболачивания, засоления, уплотнения и другое $[9,10]$.

В настоящие время проблема ведения землеустройства актуальна, так как в нашей стране землеустроительные мероприятия реализуются очень медленно, замедляя рост социального и экономического развития. Недостаток финансирования сферы землеустройства и соответствующих организации, отказ от разработки, установленной Федеральным законом (Ф3) Российской Федерации (РФ) от 18.06.2001 №78-Ф3 «О землеустройстве» [11] землеустроительной документации, привели к следующим проблемам землеустройства:

- разрушению сельскохозяйственной инфраструктуры;

- потере достоверной информации, а также потере баз данных о качественном и количественном состоянии земель; 
- появлению пространственных недостатков (вкрапливание, вклинивание, чересполосица, топографическая чересполосица). Недостатки землепользований сельскохозяйственных предприятий возникают чаще всего вследствие сложного процесса формирования земельных массивов сельскохозяйственных предприятий и приводят к большим финансовым затратам на предотвращения данных проблем;

- изъятию особо ценных сельскохозяйственных земель для целей промышленности и автотранспорта [1].

В табл. 1 представлена систематизация землеустроительных мероприятий и документов, а также выполнена оценка эффективности их проведения.

Таблица 1

Виды землеустроительных мероприятий

\begin{tabular}{|c|c|c|c|}
\hline $\begin{array}{c}\text { Виды землеустрои- } \\
\text { тельных мероприятий }\end{array}$ & $\begin{array}{c}\text { Цель землеустроитель- } \\
\text { ных мероприятий }\end{array}$ & $\begin{array}{c}\text { Результат землеустро- } \\
\text { ительных мероприятий } \\
\text { (документация) }\end{array}$ & $\begin{array}{l}\text { Современное } \\
\text { состояние }\end{array}$ \\
\hline 1 & 2 & 3 & 4 \\
\hline $\begin{array}{l}\text { Оценка качества зе- } \\
\text { мель }\end{array}$ & $\begin{array}{l}\text { Получения данных о } \\
\text { свойствах земли как } \\
\text { средства производства в } \\
\text { сельском хозяйстве }\end{array}$ & $\begin{array}{l}\text { Атласы и тематические } \\
\text { карты, состояния и ис- } \\
\text { пользования земель }\end{array}$ & $\begin{array}{l}\text { Проводятся } \\
\text { фрагментарно }\end{array}$ \\
\hline $\begin{array}{l}\text { Геоботанические, поч- } \\
\text { венные и другие изыс- } \\
\text { кания и обследования }\end{array}$ & $\begin{array}{l}\text { Получения информации } \\
\text { о почве и состоянии зе- } \\
\text { мель, а также в целях } \\
\text { выявления земель, под- } \\
\text { верженных ветровой } \\
\text { эрозии, водной, селям, } \\
\text { заболачиванию, подтоп- } \\
\text { лению, вторичному за- } \\
\text { солению, уплотнению, } \\
\text { иссушению, загрязне- } \\
\text { нию отходами потребле- } \\
\text { ния и производства, хи- } \\
\text { мическими и радиоак- } \\
\text { тивными веществами, } \\
\text { заражению и иными } \\
\text { негативным воздй- } \\
\text { ствиям }\end{array}$ & $\begin{array}{l}\text { Материалы геоботани- } \\
\text { ческих, почвенных и } \\
\text { других изысканий и об- } \\
\text { следований, инвента- } \\
\text { ризации r земель, } \\
\text { оценки качества земель }\end{array}$ & $\begin{array}{l}\text { Проводятся } \\
\text { фрагментарно }\end{array}$ \\
\hline $\begin{array}{l}\text { Внутрихозяйственное } \\
\text { землеустройство }\end{array}$ & $\begin{array}{l}\text { Организации рацио- } \\
\text { нального использования } \\
\text { земель сельскохозяй- } \\
\text { ственного назначения } \\
\text { и их охраны, а также зе- } \\
\text { мель, используемых об- } \\
\text { щинами и лицами отно- } \\
\text { сящихся к коренным ма- } \\
\text { лочисленным народов } \\
\text { Сибири, Севера и Даль- } \\
\text { него Востока РФ для } \\
\text { обеспечения их тради- } \\
\text { ционного образа жизни }\end{array}$ & $\begin{array}{l}\text { Проекты внутрихозяй- } \\
\text { ственного } \\
\text { устройства }\end{array}$ & $\begin{array}{l}\text { Проводятся } \\
\text { фрагментарно }\end{array}$ \\
\hline
\end{tabular}


Окончание табл. 1

\begin{tabular}{|c|c|c|c|}
\hline $\begin{array}{c}\text { Виды землеустрои- } \\
\text { тельных мероприятий }\end{array}$ & $\begin{array}{c}\text { Цель землеустроитель- } \\
\text { ных мероприятий }\end{array}$ & $\begin{array}{c}\text { Результат землеустро- } \\
\text { ительных мероприятий } \\
\text { (документация) }\end{array}$ & $\begin{array}{c}\text { Современное } \\
\text { состояние }\end{array}$ \\
\hline $\begin{array}{l}\text { Описание местополо- } \\
\text { жения границ объек- } \\
\text { тов землеустройства } \\
\text { и установление их на } \\
\text { местности }\end{array}$ & $\begin{array}{l}\text { Проводится в целях тек- } \\
\text { стового и координатного } \\
\text { описания местоположе- } \\
\text { ния границ муниципаль- } \\
\text { ных образований и субъ- } \\
\text { ектов РФ для внесения } \\
\text { сведений в Единый госу- } \\
\text { дарственный реестр не- } \\
\text { движимости (ЕГРН) }\end{array}$ & $\begin{array}{l}\text { Карты (планы) объек- } \\
\text { тов землеустройства }\end{array}$ & $\begin{array}{l}\text { Проводятся } \\
\text { фрагментарно }\end{array}$ \\
\hline $\begin{array}{l}\text { Планирование и орга- } \\
\text { низация рациональ- } \\
\text { ного использования } \\
\text { земель и их охраны }\end{array}$ & $\begin{array}{l}\text { Улучшение распределе- } \\
\text { ния земель в соответ- } \\
\text { ствии с перспективами } \\
\text { развития экономики, со- } \\
\text { вершенствование орга- } \\
\text { низации территорий и } \\
\text { определения других } \\
\text { направлений рациональ- } \\
\text { ного использования зе- } \\
\text { мель и их охраны в РФ, } \\
\text { муниципальных образо- } \\
\text { ваниях и субъектах РФ. }\end{array}$ & $\begin{array}{l}\text { Схема землеустрой- } \\
\text { ства территорий субъ- } \\
\text { ектов РФ, генеральная } \\
\text { схема землеустройства } \\
\text { территории РФ, схемы } \\
\text { использования } \\
\text { охраны земель, схема } \\
\text { землеустройства муни- } \\
\text { ципальных образова- } \\
\text { ний. }\end{array}$ & $\begin{array}{l}\text { Проводятся } \\
\text { фрагментарно }\end{array}$ \\
\hline $\begin{array}{l}\text { Инвентаризация зе- } \\
\text { мель }\end{array}$ & $\begin{array}{l}\text { Проводится с целью вы- } \\
\text { явления нерационально } \\
\text { используемых, неис- } \\
\text { пользуемых или исполь- } \\
\text { зуемых не по целевому } \\
\text { предназначению и не } \\
\text { в соответствии с разре- } \\
\text { шенным использова- } \\
\text { нием ЗУ или иных харак- } \\
\text { теристик земель. }\end{array}$ & $\begin{array}{l}\text { Проекты улучшения } \\
\text { сельскохозяйственных } \\
\text { угодий, рекультивации } \\
\text { нарушенных земель, } \\
\text { освоения новых зе- } \\
\text { мель, защиты земель от } \\
\text { селей, эрозии, вторич- } \\
\text { ного засоления, уплот- } \\
\text { нения, подтопления, } \\
\text { заболачивания, загряз- } \\
\text { нение отходами и дру- } \\
\text { гое. }\end{array}$ & $\begin{array}{l}\text { Проводятся } \\
\text { фрагментарно }\end{array}$ \\
\hline
\end{tabular}

Минэкономразвития РФ отмечает, что у Федерального закона «О землеустройстве», который был принят 18.06.2001, не определен предмет землеустройства, случаи проведения землеустроительных мероприятий, не определены полномочия органов исполнительной власти в связи с проведением отдельных землеустроительных работ.

В результате, землеустроительные мероприятия и подготовка документации по землеустройству практически не проводятся. Тем самым государственная политика в области землеустройства осуществляется слабо.

В связи с недостатками действующего законодательства разработан проект федерального закона «О землеустройстве» [10]. 
Проект уточняет понятие землеустройства: под ним понимается взаимосвязанные мероприятия по обеспечению условий для наилучшего использования земель, расположенных в зоне, предусматривающей ведение сельского хозяйства (земли сельскохозяйственного назначения). Документ наделён полномочиями по утверждению признаков ненадлежащего использования земель, которые используются в сельскохозяйственном назначении, и наличие которых является основанием для изъятия участков [10].

Целями землеустройства являются в соответствии с проектом федерального закона являются:

- восстановление и сохранение природных ландшафтов и достопримечательных мест в той мере, в какой это может быть обеспечено посредством землеустройства;

- формирование условий для повышения производительности сельского хозяйства;

- сохранение уклада жизни сельского населения, обеспечение традиционного образа жизни коренных малочисленных народов Сибири, Севера и Дальнего Востока, устойчивое развитие сельских территорий;

- обеспечение надлежащего использования земель, на которых ведется сельское хозяйство.

Задачами землеустройства являются:

- повышение и сохранение плодородия земель посредством проведения работ и землеустроительных мероприятий, а также агрохимических и мелиоративных мероприятий;

- устранение сформировавшихся недостатков землепользования и предотвращение новых;

- определение наиболее подходящих видов разрешенного использования земельных участков с учетом плодородия почв и существующих способов ведения сельского хозяйства.

В табл. 2 приведена сравнительная характеристика основных положений 78ФЗ и нового проекта Федерального закона «О землеустройстве».

Таблиия 2

Сравнительная характеристика 78-ФЗ и нового проект Федерального закона «О землеустройстве»

\begin{tabular}{|c|c|}
\hline $\begin{array}{c}\text { Федеральный закон «О землеустройстве» от } \\
18.06 .2001 \text { N 78-Ф3 }\end{array}$ & $\begin{array}{c}\text { Проект нового Федерального закона } \\
\text { «О землеустройстве» }\end{array}$ \\
\hline 1 & 2 \\
\hline \multicolumn{2}{|c|}{ Объекты землеустройства } \\
\hline $\begin{array}{l}\text { Территории муниципальных образований, } \\
\text { субъекты РФ, территориальные зоны, террито- } \\
\text { рии населенных пунктов, зоны с особыми } \\
\text { условиями использования территорий и части } \\
\text { указанных территорий и зон. }\end{array}$ & $\begin{array}{l}\text { Земли сельскохозяйственного назначе- } \\
\text { ния. }\end{array}$ \\
\hline
\end{tabular}


Продолжение табл. 2

\begin{tabular}{|c|c|}
\hline $\begin{array}{c}\text { Федеральный закон «О землеустройстве» от } \\
18.06 .2001 \text { N 78-Ф3 }\end{array}$ & $\begin{array}{c}\text { Проект нового Федерального закона } \\
\text { «О землеустройстве» }\end{array}$ \\
\hline 1 & 2 \\
\hline \multicolumn{2}{|c|}{ Землеустроительные мероприятия } \\
\hline $\begin{array}{l}\text { 1. Планирование и организация рационального } \\
\text { использования земель и их охрана. } \\
\text { 2. Мероприятия по изучению состояния земель. } \\
\text { 3. Описания местоположения границ и установ- } \\
\text { ления на местности границ объектов земле- } \\
\text { устройства. } \\
\text { 4. Организации рационального использования } \\
\text { юридическими лицами и гражданами и ЗУ для } \\
\text { осуществления сельскохозяйственного произ- } \\
\text { водства. }\end{array}$ & $\begin{array}{l}\text { 1. Планирование использования земель. } \\
\text { 2. Изучение состояния земель. } \\
\text { 3. Выполнение проекта землеустрой- } \\
\text { ства. } \\
\text { 4. Подготовка проекта землеустройства. } \\
\text { 5. Надзор за выполнением проекта земле- } \\
\text { устройства. } \\
\text { 6. Подготовка сельскохозяйственного ре- } \\
\text { гламента. }\end{array}$ \\
\hline
\end{tabular}

Виды землеустроительных работ

1. Оценка качества земель.

2. Почвенные, геоботанические и другие обследования и изыскания.

3. Геодезические и картографические работы.

4. Инвентаризация земель.

5. Внутрихозяйственное землеустройство.

6. Описание местоположения границ объектов землеустройства.

7. Планирование и организация рационального использования земель и их охраны.

8. Установление на местности границ объектов землеустройства.
1. Установление параметров, видов и местоположения вновь возводимых сооружений, зданий.

2. Установление видов разрешенного использования ЗУ и соотнесение их с сельскохозяйственными угодьями и устройство севооборотов.

3. Работы, связанные с образованием ЗУ (за исключением кадастровых работ).

4. Определение места размещения жилого дома на ЗУ.

5. Организация и проектирование строительства и гидротехнических сооружений, мелиоративных сооружений, требуемых для ведения сельского хозяйства.

6. Организация и проектирование строительства необходимых для ведения сельского хозяйства защитных сооружений, скотопрогонных и полевых дорог, инженерных сооружений, требуемых для ведения сельского хозяйства.

7. Устройство и проектирование защитных лесных насаждений.

8. Организация использования кормовых угодий.

9. Картографические и геодезические работы, изыскательские работы, обеспечивающие землеустройство.

10. Устройство ЗУ для посадки многолетних плодово-ягодных насаждений. 
Окончание табл. 2

\begin{tabular}{|c|c|}
\hline $\begin{array}{c}\text { Федеральный закон «О землеустройстве» от } \\
\text { 18.06.2001 N 78-Ф3 }\end{array}$ & $\begin{array}{c}\text { Проект нового Федерального закона } \\
\text { «О землеустройстве» }\end{array}$ \\
\hline 1 & 2 \\
\hline \multicolumn{2}{|c|}{ Землеустроительная документация } \\
\hline $\begin{array}{l}\text { Атласы и тематические карты, состояния и ис- } \\
\text { пользования земель, материалы геоботаниче- } \\
\text { ских, почвенных и других изысканий и обсле- } \\
\text { дований, инвентаризации земель, оценки каче- } \\
\text { ства земель, проекты внутрихозяйственного } \\
\text { землеустройства, карты (планы) объектов зем- } \\
\text { леустройства, схема землеустройства террито- } \\
\text { рий субъектов РФ, генеральная схема земле- } \\
\text { устройства территории РФ, схемы использова- } \\
\text { ния и охраны земель, схема землеустройства } \\
\text { муниципальных образований. }\end{array}$ & $\begin{array}{l}\text { Землеустроительная карта, проект земле- } \\
\text { устройства, сельскохозяйственный регла- } \\
\text { мент, а также соглашение о проведении } \\
\text { землеустройства, отчет о землеустрои- } \\
\text { тельном надзоре, материалы землеустрои- } \\
\text { тельных изысканий. }\end{array}$ \\
\hline
\end{tabular}

Можно сделать вывод о том, что новый проект Федерального закона «О землеустройстве» кардинально отличается от ФЗ №78 «О землеустройстве» и основным документом, который будет подготавливаться в рамках нового закона, станет проект землеустройства.

Таким образом, новый Федеральный закон «О землеустройстве» будет регулировать использование только земель сельскохозяйственного назначения, то есть территорий, на которых непосредственно осуществляется сельскохозяйственное производство. Землеустроительные мероприятия и документы, предусмотренные новым законом, будут направлены на рациональное планирование и использование, планомерное восстановление земель сельскохозяйственного назначения, что положительно скажется на качестве земельных ресурсов нашей страны.

\section{БИБЛИОГРАФИЧЕСКИЙ СПИСОК}

1. Аксёнова Е. Г., Гаранова М. В. Актуальные проблемы землеустройства и кадастра [Текст] / Е.Г. Аксёнова, М.В. Гаранова // Текст научной статьи по специальности «Экономика и бизнес». Ростов на Дону, 2017.

2. Барсукова С.Ю., Звягинцев В.И. Земельная реформа в России в 1990-2000-е годы, или как в ходе ведомственных реорганизаций «Реформировали» земельную реформу [Текст] // С.Ю. Барсукова, В.И. Звягинцева // Текст научной статьи по специальности «История и археология».

3. Бравок К.А. Проблемы процесса ведения землеустройства и кадастра. Текст научной статьи по специальности «Экономика и бизнес». [Текст] / К.А. Бравок - г. Владивосток РФ 2017 .

4. Жарников В.Б. Рациональное использование земель и основные условия его реализации [Текст] / В.Б. Жарнков. - Новосибирск: Сибирский государственный университет геосистем и технологий, 2017. - 179с. 
5. Вараксин Г.С., Вершинский И.С., Байкалов Е.М. История, состояние и перспективы землеустройства в России [Текст] // - Г.С. Вараксин, И.С. Вершинский, Е.М. Байкалов // Текст научной статьи по специальности «Социальная и экономическая география».

6. Васильева Н. В. Основы землепользования и землеустройства [Текст]: учебник и практикум для академического бакалавриата / Н. В. Васильева. - Москва: Издательство Юрайт, 2019. - $376 \mathrm{c}$.

7. Виды землеустройства [Электронный ресурс] / Режим доступа: https://spravochnick.ru/geodeziya/zemleustroystvo_v_rossii/vidy_zemleustroystva/ - Загл. с экрана.

8. Волков С.Н. Генеральная схема землеустройства территории Российской Федерации (содержание и методы разработки) [Текст] // - С.Н. Волков //: монография. М., 2017. - С. 88.

9. Волков С.Н. Землеустройство: Теоретические основы землеустройства: учеб. пособие ) [Текст] // С.Н. Волков. - М.: Колос, 2001. - 496 с.

10. О землеустройстве Проект Федерального закона 28.01.2019 [Электронный ресурс] // СПС «КонсультантПлюс» http://www.consultant.ru/cons/cgi/online.cgi?req=doc;base=PRJ;n=180130\#09522275662436688.

11. О землеустройстве. Федеральный закон от 18.06.2001 N 78-Ф3 (ред. от 13.07.2015) (с изм. и доп., вступ. в силу с 01.01.2016) [Электронный ресурс] // СПС «КонсультантПлюс»Режим доступа: http://www.consultant.ru/document/cons_doc_LAW_32132/.

(C) Н. О. Митрофанова, Н. И. Добротворская, В. И. Норкин, А. С. Свирина, 2021 